Check for updates

Cite this: J. Mater. Chem. A, 2022, 10 2559

Received 19th August 2021

Accepted 21st December 2021

DOI: $10.1039 / \mathrm{d} 1 \mathrm{ta0} 1113 \mathrm{k}$

rsc.li/materials-a

\section{High-performance protonic ceramic fuel cell cathode using protophilic mixed ion and electron conducting material $\dagger$}

\author{
Dingyue Hu, Junyoung Kim, Hongjun Niu, Luke M. Daniels, (D) Troy D. Manning, \\ Ruiyong Chen, (D) Bowen Liu, Richard Feetham, John B. Claridge \\ and Matthew J. Rosseinsky (D)*
}

\begin{abstract}
Protonic ceramic fuel cells (PCFCs) are attractive energy conversion devices for intermediate-temperature operation $\left(400-600^{\circ} \mathrm{C}\right)$, however widespread application of PCFCs relies on the development of new highperformance electrode materials. Here we report the electrochemical and protonic properties of a selfassembled nanocomposite, $\mathrm{Ba}_{0.5} \mathrm{Sr}_{0.5}\left(\mathrm{Co}_{0.7} \mathrm{Fe}_{0.3}\right)_{0.6875} \mathrm{~W}_{0.3125} \mathrm{O}_{3-\delta}$ (BSCFW) consisting of a disordered single perovskite and an ordered double perovskite phase, as a PCFC cathode material. BSCFW shows thermodynamic and kinetic protonic behaviour conducive to PCFC application with favourable proton defect formation enthalpy $\left(\Delta H=-35 \pm 7 \mathrm{~kJ} \mathrm{~mol}^{-1}\right)$ comparable to existing proton conducting electrolyte materials. BSCFW presents an excellent polarization resistance $\left(R_{\mathrm{p}}\right)$ of $0.172(2) \Omega \mathrm{cm}^{2}$ at $600{ }^{\circ} \mathrm{C}$ and a high power density of $582(1) \mathrm{mW} \mathrm{cm}^{-2}$ through single-cell measurement, which is a comparable performance to current state-of-the-art cathode materials. BSCFW exhibits good chemical and thermal stability against $\mathrm{BaZr}_{0.1} \mathrm{Ce}_{0.7} \mathrm{Y}_{0.1} \mathrm{Yb}_{0.1} \mathrm{O}_{3-\delta}$ (BZCYYb) electrolyte with a low $R_{\mathrm{p}}$ degradation rate of 1.0(1) $\times 10^{-6} \Omega \mathrm{cm}^{2} \mathrm{~min}^{-1}$. These performance and stability figures represent an advance beyond those of $\mathrm{Ba}_{0.5} \mathrm{Sr}_{0.5} \mathrm{Co}_{0.7} \mathrm{Fe}_{0.3} \mathrm{O}_{3-\delta}$ (BSCF), which is unstable under the same conditions and is incompatible with the electrolyte material. Our comprehensive characterization of the protonic properties of BSCFW, whose performance and stability are ensured via the interplay of the single and double perovskite phases, provides fundamental understanding that will inform the future design of high-performance PCFC cathodes.
\end{abstract}

\section{Introduction}

Amongst the various type of fuel cells, ceramic fuel cells have been extensively studied as eco-friendly alternative energy devices as a result of high energy conversion efficiency and continuous production of electricity without pollutant emissions. ${ }^{1}$ The high operating temperature $\left(>800{ }^{\circ} \mathrm{C}\right)$ of conventional $\mathrm{O}^{2-}$ conducting ceramic fuel cells (solid oxide fuel cells, SOFCs), however, leads to serious issues such as chemical interdiffusion and high thermal stress..$^{2-5}$ Protonic ceramic fuel cells (PCFCs) using proton-conducting oxides (PCOs) are promising candidates for intermediate to low temperature operation (400$600^{\circ} \mathrm{C}$ ) because of the relatively high ionic conductivity and low activation energy for $\mathrm{H}^{+}$transport compared with $\mathrm{O}^{2-}$ transport in conventional $\mathrm{O}^{2-}$ conducting oxides under the same operating conditions. ${ }^{6}$

Department of Chemistry, Materials Innovation Factory, University of Liverpool, 51 Oxford Street, Liverpool, L7 3NY, UK. E-mail: m.j.rosseinsky@liverpool.ac.uk

$\dagger$ Electronic supplementary information (ESI) available. See DOI: $10.1039 / \mathrm{d} 1 \mathrm{ta} 07113 \mathrm{k}$
The first report of high-temperature proton conductivity in oxide materials by Iwahara and co-workers in the 1980s garnered significant research interest for developing PCOs based on barium-zirconates and -cerates as electrolyte materials. ${ }^{7,8}$ Aliovalent-doped $\mathrm{BaCe}_{1-x} \mathrm{Zr}_{x} \mathrm{O}_{3-\delta}(0<x<1)$ have demonstrated high proton conductivity overcoming the major issues such as poor sinterability of $\mathrm{BaZrO}_{3-\delta}$ and low proton conductivity of $\mathrm{BaCeO}_{3-\delta}$ under practical operating conditions. ${ }^{9-11} \mathrm{~A}$ barium zirconate-cerate co-doped with $\mathrm{Y}$ and $\mathrm{Yb}$, $\mathrm{BaZr}_{0.1} \mathrm{Ce}_{0.7} \mathrm{Y}_{0.1} \mathrm{Yb}_{0.1} \mathrm{O}_{3-\delta}$ (BZCYYb), is reported with high ionic conductivity $\left(\sim 0.01 \mathrm{~S} \mathrm{~cm}^{-1}\right.$ in a humidified $\mathrm{O}_{2}$ atmosphere), and excellent tolerance to sulfur poisoning and coking ${ }^{12}$ while BZCYYb with A-site barium deficiency showed chemical instability under both $\mathrm{CO}_{2}$ and $\mathrm{H}_{2} \mathrm{~S}$ atmosphere. ${ }^{13}$ However, despite such performance from the electrolyte, the limiting factor that prevents the widespread application of PCFCs is the limited availability of cathode materials with high activity and/or stability.

Generally, mixed ionic $\left(\mathrm{O}^{2-}\right)$ and electronic conductors (MIECs) have been used as the cathode material for conventional SOFC systems because of their excellent electronic conductivity and catalytic activity for the oxygen reduction 
reaction. However, for MIECs with poor proton conductivity, electrochemical activity is localized to the interface between cathode and electrolyte, as protons diffuse from the PCO electrolyte to the cathode material in order to generate electricity. Triple conducting oxides (TCOs), that allow simultaneous transport of $\mathrm{H}^{+}, \mathrm{O}^{2-}$ and $\mathrm{e}^{-\mathbf{1 4 , 1 5}}$ with high chemical stability are required to effectively extend the electrochemically active sites to the entire surface of the cathode, ${ }^{\mathbf{1 6}}$ and two different approaches have been used to increase the electrochemical performance of TCOs. The first approach is to dope various aliovalent elements ( $\mathrm{Co}, \mathrm{Fe}, \mathrm{Sc}, \mathrm{Y}$ ) into pure proton-conducting oxides (i.e. $\mathrm{BaZrO}_{3-\delta}$ or $\mathrm{BaCeO}_{3-\delta}$ ) to enhance their electrochemical conductivity of $\mathrm{O}^{2-}$ and $\mathrm{e}^{-} \cdot .^{17-19}$ Trivalent cations are doped into the B-site of perovskite PCOs to increase oxygen-ion kinetics, and the O'Hayre group reported that transition-metal cations ( $\mathrm{Co}$ and $\mathrm{Fe}$ ) doped into $\mathrm{BaZr}_{x} \mathrm{Y}_{1-x} \mathrm{O}_{3-\delta}$ significantly improve its catalytic properties as a PCFC cathode by activating electronic conduction while maintaining existing ionic conductivity. ${ }^{20}$ The second approach is to target existing MIEC $\left(\mathrm{O}^{2-} / \mathrm{e}^{-}\right)$materials with protophilic properties. ${ }^{21}$ This approach has the advantage that the material is already well-studied and its reaction mechanisms of $\mathrm{O}^{2-}$ and $\mathrm{e}^{-}$are understood. Several researchers have investigated the proton properties of typical MIEC perovskite-related materials, such as $\mathrm{BaCoO}_{3}$, which exhibit excellent electrochemical properties. ${ }^{22-24}$

Among those $\mathrm{BaCoO}_{3}$-based materials, $\mathrm{Ba}_{0.5} \mathrm{Sr}_{0.5} \mathrm{Co}_{0.8} \mathrm{Fe}_{0.2^{-}}$ $\mathrm{O}_{3-\delta}$ (BSCF) exhibits excellent electrochemical performance as a SOFC cathode. ${ }^{25}$ However, BSCF has been limited for use as a PCFC cathode because of its chemical instability under PCFC operating conditions (e.g., after hydration treatment ${ }^{26,27}$ and degradation of the electrochemical performance below $650{ }^{\circ} \mathrm{C}$ in humidified air. ${ }^{28}$ We previously reported the self-assembled dynamic perovskite composite material, $\mathrm{Ba}_{0.5} \mathrm{Sr}_{0.5}\left(\mathrm{Co}_{0.7^{-}}\right.$ $\left.\mathrm{Fe}_{0.3}\right)_{0.6875} \mathrm{~W}_{0.3125} \mathrm{O}_{3-\delta}$ (BSCFW), as an SOFC cathode. ${ }^{29}$ By incorporating $\mathrm{W}^{6+}$ into BSCF, BSCFW self-assembles into a composite where the interplay between a majority phase ( $\sim 71 \%$ ) of stable oxygen-stoichiometric and electronically conducting double perovskite (DP), and a relatively minor phase ( $\sim 29 \%$ ) of highly electro-catalytically active MIEC single perovskite (SP), ensures a combination of low polarization resistance $\left(R_{\mathrm{p}}\right)$ with chemical and microstructural stability via coherent, quasi-epitaxial interfaces between the phases. The weight ratio of DP and SP phase in BSCFW is $\sim 7: 3$. This enhanced stability and high performance provided by this self-assembly identifies BSCFW as a candidate for PCFC cathode materials.

Here we report the high electrochemical performance of BSCFW as a PCFC cathode material with comprehensive characterization of protonic properties. The thermodynamic protonation enthalpy of BSCFW is evaluated by thermogravimetric analysis (TGA). The electrochemical performance of BSCFW as a PCFC cathode is examined through single-cell tests. Our findings highlight the excellent performance of the perovskite composite BSCFW and detailed characterization of the material provides insight and understanding towards the development of more efficient high-performance PCFC electrode materials.

\section{Experimental}

\section{Synthesis of electrolyte and electrode powders}

The solid-state reaction method was used to synthesize $\mathrm{Ba}_{0.5^{-}}$ $\mathrm{Sr}_{0.5}\left(\mathrm{Co}_{0.7} \mathrm{Fe}_{0.3}\right)_{0.6875} \mathrm{~W}_{0.3125} \mathrm{O}_{3-\delta} \quad$ (BSCFW). Stoichiometric amounts of $\mathrm{BaCO}_{3}$ (99.995\%), $\mathrm{SrCO}_{3}$ (99.994\%), $\mathrm{Co}_{3} \mathrm{O}_{4}$ (99.7\%), $\mathrm{Fe}_{2} \mathrm{O}_{3}(99.99 \%)$, and $\mathrm{WO}_{3}(99.9 \%)$ were weighed and ball milled in $15 \mathrm{~mL}$ propan-2-ol for $14 \mathrm{~h}$ with $\mathrm{ZrO}_{2}$ balls (10 $\mathrm{mm}$ diameter) using a Fritsch Pulverisette 7 Planetary Mill (350 rpm). The milled powder was dried and calcined at $700{ }^{\circ} \mathrm{C}$ for $6 \mathrm{~h}$ and $900{ }^{\circ} \mathrm{C}$ for $8 \mathrm{~h}$ with heating and cooling rates of $5{ }^{\circ} \mathrm{C} \mathrm{min}{ }^{-1}$ in air. The calcined BSCFW powder was pressed into $10 \mathrm{~mm}$ diameter pellet and sintered at $1200{ }^{\circ} \mathrm{C}$ for $12 \mathrm{~h}$ in a zirconia crucible. The relative density of sintered BSCFW pellet is $94 \%$. $\mathrm{BaZr}_{0.1} \mathrm{Ce}_{0.7} \mathrm{Y}_{0.1} \mathrm{Yb}_{0.1} \mathrm{O}_{3-\delta}$ (BZCYYb) powder was synthesized by the solid-state reaction. Stoichiometric amounts of $\mathrm{BaCO}_{3}$ (99\%, Sigma Aldrich), $\mathrm{CeO}_{2}$ (99.9\%, Sigma Aldrich), $\mathrm{ZrO}_{2}$ (99\%, Alfa Aesar), $\mathrm{Y}_{2} \mathrm{O}_{3}$ (99.99\%, Alfa Aesar), and $\mathrm{Yb}_{2} \mathrm{O}_{3}$ (99.9\%, Alfa Aesar) were mixed by the ball milling process, followed by sintering at $1200{ }^{\circ} \mathrm{C}$ for $12 \mathrm{~h}$ in air.

\section{Preparation of samples for SEM and XRD analysis}

BSCFW-BZCYYb mixtures are sintered at $950{ }^{\circ} \mathrm{C}$ in air for $4 \mathrm{~h}$, to investigate the chemical reactivity between the BSCFW and BZCYYb. The chemical reactivity of BSCFW and BZCYYb powders was checked by an X-ray diffractometer (Panalytical X'Pert Pro Bragg-Brentano geometry laboratory X-ray diffractometer with Co $\mathrm{K} \alpha_{1}$ radiation, $\lambda=1.78898 \AA$ ). Synchrotron $\mathrm{X}$ ray diffraction data of powder samples were recorded on Beamline I11 with a wide-angle position sensitive detector $(\lambda=$ $0.826596(10) \AA$ A) at Diamond Light Source with samples loaded in borosilicate capillaries. The microstructures and crosssection images of the NiO-BZCYYb $\mid$ BZCYYb|BSCFW single cell were observed using scanning electron microscopy (Hitachi S4800).

\section{Fabrication of single-cell}

The NiO-BZCYYb anode-supported cell was fabricated for fuel cell durability and performance. NiO-BZCYYb supported cells were fabricated by the drop-coating method to form the electrolyte layer. The NiO-BZCYYb hydrogen electrode was prepared by a mixture of NiO and BZCYYb (weight ratio of $6.5: 3.5$ ) after being ball-milled ( $5 \mathrm{~mm}$ balls, $100 \mathrm{rpm}$ ) for $24 \mathrm{~h}$ in ethanol. The BZCYYb suspension was applied to the NiO-BZCYYb support by drop-coating, followed by drying in air and co-sintering at $1400{ }^{\circ} \mathrm{C}$ for $4 \mathrm{~h}$. The diameter of the single cell after sintering is $1.025 \mathrm{~cm}$ (shown in Fig. S1 $\dagger$ ). The calcined BSCFW powder was blended with a binder (Heraeus V006) at a weight ratio of $1: 0.7$ for air electrode slurries. Air electrode slurries were screenprinted onto the surface of the BZCYYb electrolyte and were finally sintered at $950{ }^{\circ} \mathrm{C}$ in air for $1 \mathrm{~h}$.

\section{Thermogravimetric analysis}

The concentration of protonic defects was determined by thermogravimetric analysis (TGA). To remove all water from the 

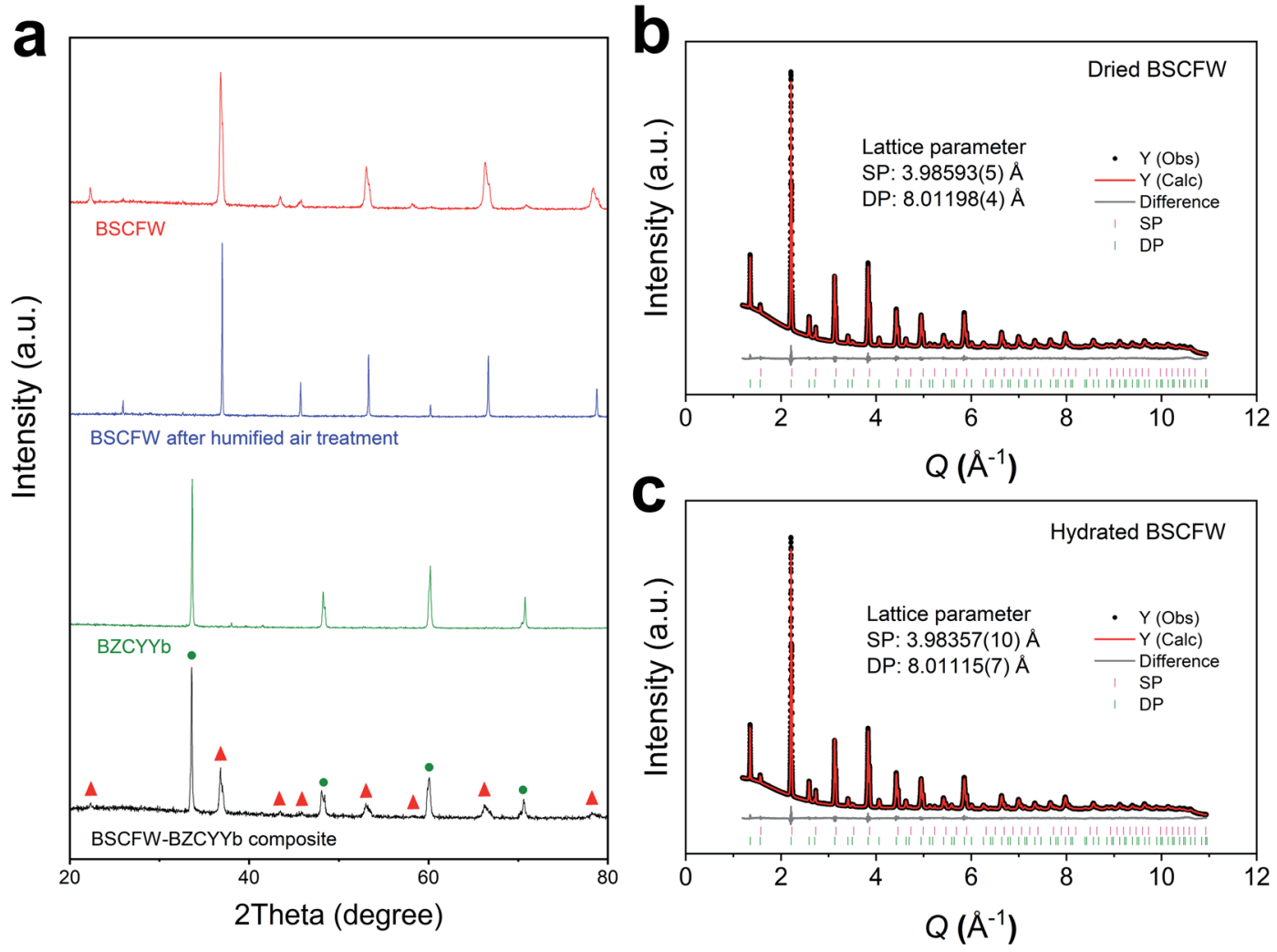

Fig. 1 (a) XRD diffraction pattern of BSCFW sintered at $1200^{\circ} \mathrm{C}$ for $12 \mathrm{~h}$ (red), BSCFW after humidified air exposure (flowing 3 vol\% $\mathrm{H}_{2} \mathrm{O}$ containing air) for $1 \mathrm{~h}$ at $300^{\circ} \mathrm{C}$ (blue), BZCYYb electrolyte sintered at $1400^{\circ} \mathrm{C}$ for $4 \mathrm{~h}$ (green), and a mixture of BSCFW and BZCYYb sintered at $950{ }^{\circ} \mathrm{C}$ $4 \mathrm{~h}$ (black). Peaks corresponding to BSCFW and BZCYYb are labeled with red triangles and green circles, respectively. Observed (black points), calculated (red line), and difference (grey line) profiles from Pawley fits of synchrotron data (beamline I11, Diamond Light Source, $\lambda=$ $0.826596(10)$ A) for (b) dried and (c) hydrated BSCFW (heated to $300^{\circ} \mathrm{C}$ for $1 \mathrm{~h}$ under flowing 3 vol\% $\mathrm{H}_{2} \mathrm{O}$ air) at room temperature. Tick marks are shown for the SP (pink) and DP (green) phases in both. B-site cations occupancy and average cation radii for BSCFW are given in Table S1. $\dagger$

structure, the powders $(60-70 \mathrm{mg})$ were heated to $800{ }^{\circ} \mathrm{C}$ in dry air and held until thermal equilibrium was reached. The weight changes of samples under dry (Fig. S4a $\dagger$ ) and wet air $\left(P_{\mathrm{H}_{2} \mathrm{O}}=\right.$ $0.023 \mathrm{~atm}$, Fig. S4b $\dagger$ ) were collected every $100{ }^{\circ} \mathrm{C}$ from $800{ }^{\circ} \mathrm{C}$ to $400{ }^{\circ} \mathrm{C}$ with a $2 \mathrm{~h}$ stabilization time at each temperature. TGA data were logged using a Q500 device from TA. Measurements were carried out on samples in platinum crucibles under dry air and wet air saturated by bubbling a constant air with a flow rate of $60 \mathrm{~mL} \mathrm{~min}{ }^{-1}$ through water at $25{ }^{\circ} \mathrm{C}$. The difference of sample weight in dry and hydrated conditions at various temperatures is interpreted as the water uptake in BSCFW.

\section{Electrochemical performances}

The preparation procedure of the symmetrical cells began with pressing $0.6 \mathrm{~g}$ BZCYYb into $10 \mathrm{~mm}$ diameter pellets that were sintered at $1400^{\circ} \mathrm{C}$ for $14 \mathrm{~h}$ in air with a heating rate and cooling rate of $2{ }^{\circ} \mathrm{C} \mathrm{min}^{-1}$ and $3{ }^{\circ} \mathrm{C} \mathrm{min}^{-1}$, respectively. The cathode slurry was screen printed onto both sides of the BZCYYb electrolyte pellet with an Aremco Screen Printer (model 3230, from Aremco) and fired in air at $950{ }^{\circ} \mathrm{C}$ for $1 \mathrm{~h}$. After firing, silver electrodes were adhered to both faces of the symmetrical cell and heated at $600{ }^{\circ} \mathrm{C}$ for $1 \mathrm{~h}$ with a heating rate $3{ }^{\circ} \mathrm{C} \mathrm{min}{ }^{-1}$. The symmetrical cell was held at $600{ }^{\circ} \mathrm{C}$ under the 3 vol\% $\mathrm{H}_{2} \mathrm{O}$ - containing air with a flow rate of $20 \mathrm{~mL} \mathrm{~min}{ }^{-1}$, collecting the impedance spectra every $30 \mathrm{~min}$ for a total time of $60 \mathrm{~h}$. For single-cell tests, $\mathrm{Ag}$ wires were attached at the cathode and anode side using $\mathrm{Ag}$ paste as a current collector. The NiOBZCYYb anode-supported single-cell was sealed fully onto one end of the alumina tube using a ceramic adhesive (Aremco, Ceramabond 552). Humidified $\mathrm{H}_{2}\left(3\right.$ vol $\% \mathrm{H}_{2} \mathrm{O}$-containing $\left.\mathrm{H}_{2}\right)$ was applied to the anode side as a fuel through a water bubbler with a flow rate of $200 \mathrm{~mL} \mathrm{~min}{ }^{-1}$, while dry air was supplied as an oxidant with a flow rate of $100 \mathrm{~mL} \min ^{-1}$ to the cathode during the single cell test. The cell operational stability test was carried out at $600{ }^{\circ} \mathrm{C}$ using BZCY721 $\left(\mathrm{BaZr}_{0.7} \mathrm{Ce}_{0.2} \mathrm{Y}_{0.1} \mathrm{O}_{3-\delta}\right.$, Fuel Cell Materials Ltd) or BZCYYb with a constant $0.6 \mathrm{~V}$ potential applied for $8 \mathrm{~h}$. Impedance spectra and $I-V$ curves were acquired with Solartron 1260 frequency response analyzer in combination with a Solartron 1287 potentiostat. The resistance is determined by using the fitting tool in the software ZView v.3.2b (Scribner Associates).

\section{Results and discussion}

The powder X-ray diffraction (XRD) patterns of phase pure cathode $\mathrm{Ba}_{0.5} \mathrm{Sr}_{0.5}\left(\mathrm{Co}_{0.7} \mathrm{Fe}_{0.3}\right)_{0.6875} \mathrm{~W}_{0.3125} \mathrm{O}_{3-\delta}$ (BSCFW) and electrolyte $\mathrm{BaZr}_{0.1} \mathrm{Ce}_{0.7} \mathrm{Y}_{0.1} \mathrm{Yb}_{0.1} \mathrm{O}_{3-\delta}$ (BZCYYb) materials and 
a
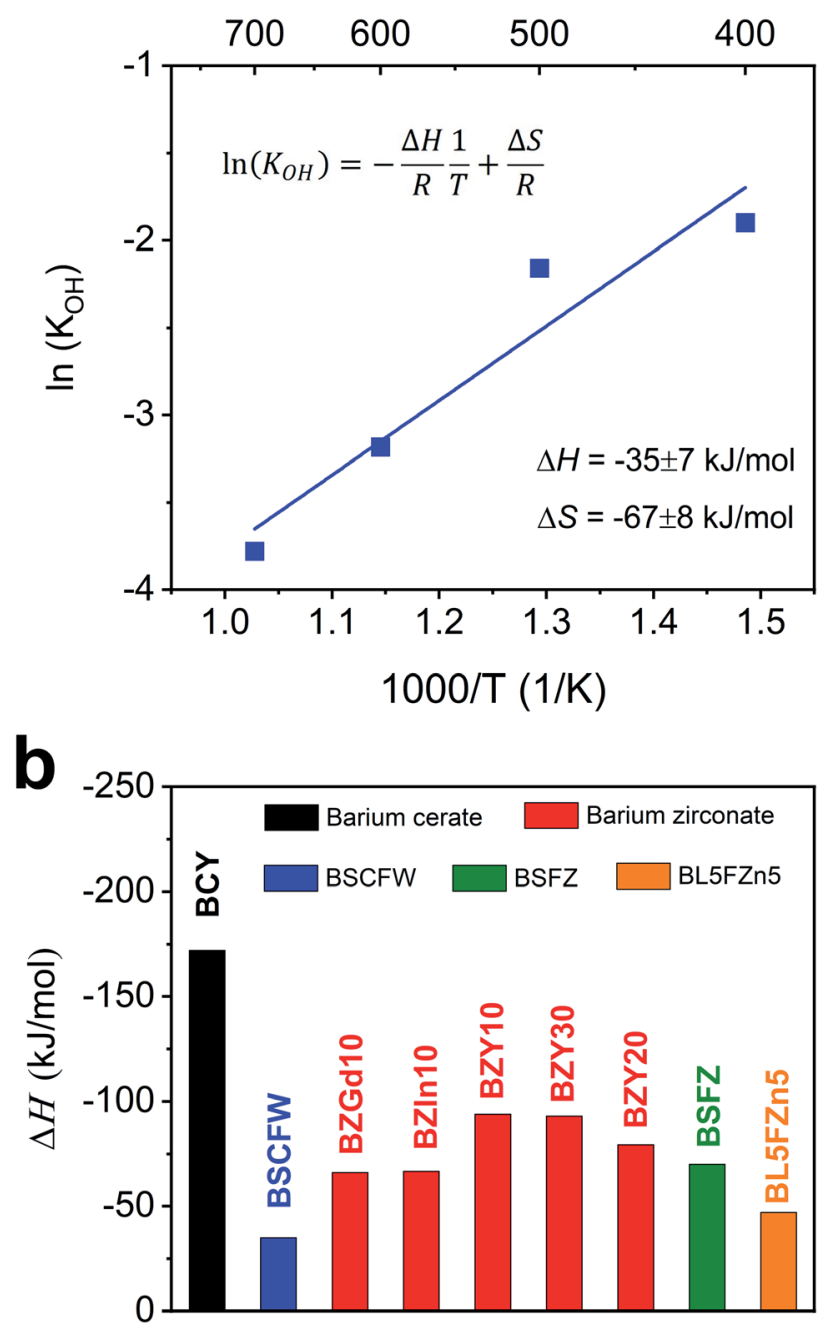

Proton-conducting materials

Fig. 2 (a) Arrhenius plot showing the equilibrium constant of hydration reaction as a function of temperature for BSCFW. The slope yields the hydration enthalpy $(\Delta H)$ of $-35 \pm 7 \mathrm{~kJ} \mathrm{~mol}^{-1}$. (b) Comparison of $\Delta H$ values with representative state-of-the-art proton-conducting oxides for electrolyte: $\quad \mathrm{BaCe}_{0.81} \mathrm{Y}_{0.19} \mathrm{O}_{3-\delta} \quad(\mathrm{BCY}),{ }^{44} \quad \mathrm{BaZr}_{0.9} \mathrm{Gd}_{0.1} \mathrm{O}_{3-\delta}$ (BZGd10), ${ }^{35} \mathrm{BaZr}_{0.9} \ln _{0.1} \mathrm{O}_{3-\delta}(\mathrm{BZIn} 10),{ }^{35} \mathrm{BaZr}_{0.7} \mathrm{Y}_{0.3} \mathrm{O}_{3-\delta}(\mathrm{BZY} 30),{ }^{41}$ $\mathrm{BaZr}_{0.8} \mathrm{Y}_{0.2} \mathrm{O}_{3-\delta}(\mathrm{BZY} 20),{ }^{40}$ and $\mathrm{BaZr}_{0.9} \mathrm{Y}_{0.1} \mathrm{O}_{3-\delta}(\mathrm{BZY} 10)^{39}$ and protonconducting oxides used as electrodes: $\mathrm{Ba}_{0.5} \mathrm{Sr}_{0.5} \mathrm{Fe}_{0.8} \mathrm{Zn}_{0.2} \mathrm{O}_{3-\delta}$ $(\mathrm{BSFZ})^{16}$ and $\mathrm{Ba}_{0.95} \mathrm{La}_{0.05} \mathrm{Fe}_{0.95} \mathrm{Zn}_{0.05} \mathrm{O}_{3-\delta}(\mathrm{BL} 5 \mathrm{FZn} 5) .{ }^{15}$

their composite powders are presented in Fig. 1a. Compatibility between BSCFW and BZCYYb is investigated by heating the mixtures at $950{ }^{\circ} \mathrm{C}$ for $4 \mathrm{~h}$. Fig. 1a shows there is no reaction between BSCFW and BZCYYb, indicating that BSCFW is chemically compatible with BZCYYb under these processing conditions. As shown in the fits against synchrotron XRD data (Fig. 1b, c and S2 $\dagger$ ), the lattice parameters of BSFCW do not significantly change between dry $\left(a_{\mathrm{SP}}=3.98593(5) \AA\right.$, $a_{\mathrm{DP}}=$ 8.01198(4) $\AA)$ and humidified air $(3 \mathrm{vol} \%)$ at $300{ }^{\circ} \mathrm{C}\left(a_{\mathrm{SP}}=\right.$ $\left.3.98357(10) \AA, a_{\mathrm{DP}}=8.01115(7) \AA\right)$. BSCFW, stabilized due to the self-assembly effect by incorporating $\mathrm{W}^{6+}$ doping, shows excellent chemical stability after exposure to $3 \mathrm{vol} \% \mathrm{H}_{2} \mathrm{O}$ in air for $1 \mathrm{~h}$ at $300{ }^{\circ} \mathrm{C}$, while BSCF powder treated under the same conditions decomposed, forming $\mathrm{Co}_{3} \mathrm{O}_{4}$ as a secondary phase (Fig. S3†). Moreover, the thermal expansion coefficient (TEC) difference between BSCFW $\left(15 \times 10^{-6} \mathrm{~K}^{-1}\right)^{29}$ and BZCYYb (100$500{ }^{\circ} \mathrm{C}: 14.2 \times 10^{-6} \mathrm{~K}^{-1}, 600-700{ }^{\circ} \mathrm{C}: 5.5 \times 10^{-6} \mathrm{~K}^{-1}$, indicating there is probably structure transformations or phase change in BZCYYb at $\left.\sim 500-600{ }^{\circ} \mathrm{C}\right)^{30}$ is smaller $\left(5.6 \%\right.$ at $\left.500{ }^{\circ} \mathrm{C}\right)$ than that between BSCF (approximately $20 \times 10^{-6} \mathrm{~K}^{-1}$ ) 31 and BZCYYb $\left(40.8 \%\right.$ at $\left.500{ }^{\circ} \mathrm{C}\right)$, suggesting BSCFW exhibits superior mechanical compatibility with the electrolyte material compared to BSCF, which will minimize or avoid cell degradation, delamination or fracture. ${ }^{2,25,32,33}$

To determine the thermodynamic protonic properties of BSCFW, the extent of $\mathrm{H}_{2} \mathrm{O}$ uptake into BSCFW was measured by thermogravimetric analysis (TGA) in the temperature range of $400-800^{\circ} \mathrm{C}$. The mass of the material was recorded as a function of temperature under dry $\left(P_{\mathrm{O}_{2}}=0.19 \mathrm{~atm}\right.$, balanced $\left.\mathrm{N}_{2}\right)$ and under humidified synthetic air $\left(P_{\mathrm{H}_{2} \mathrm{O}}=0.023 \mathrm{~atm}\right)$. When exposed to humidified air $\left(3 \mathrm{vol} \% \mathrm{H}_{2} \mathrm{O}\right)$ under an isothermal condition (sample held for $2 \mathrm{~h}$ in $100^{\circ} \mathrm{C}$ steps in the range 400$800^{\circ} \mathrm{C}$ ), the BSCFW sample absorbed water due to the hydration reaction as described in Kröger-Vink notation below (eqn (1), Fig. S4†).

$$
\mathrm{H}_{2} \mathrm{O}(\text { gas })+\mathrm{V}_{\mathrm{O}}^{*}+\mathrm{O}_{\mathrm{O}}^{\times} \leftrightarrow 2 \mathrm{OH}_{\mathrm{O}}^{\cdot}
$$

Thus, the equilibrium constant $\left(K_{\mathrm{OH}}\right)$ for the hydration reaction can be expressed as,

$$
K_{\mathrm{OH}}=\frac{\left[\mathrm{OH}_{\mathrm{O}}^{*}\right]^{2}}{P_{\mathrm{H}_{2} \mathrm{O}}\left[\mathrm{V}_{\mathrm{O}}^{*}\right]\left[\mathrm{O}_{\mathrm{O}}^{\times}\right]}
$$

where $\left[\mathrm{OH}_{\mathrm{O}}^{*}\right],\left[\mathrm{V}_{\mathrm{O}}^{*}\right]$, and $\left[\mathrm{O}_{\mathrm{O}}^{\times}\right]$are, respectively, the proton, oxygen vacancy, and oxygen concentrations of the sample in the hydrated state. Following the previous study of BSCFW, the oxidation state of B-site cations $\mathrm{Co}, \mathrm{Fe}$ and $\mathrm{W}$ are $+2 /+3,+3$ and +6 respectively. ${ }^{29}$ Then, the BSCFW composition $\mathrm{Ba}_{0.5} \mathrm{Sr}_{0.5^{-}}$ $\mathrm{Co}_{0.48125} \mathrm{Fe}_{0.20637} \mathrm{~W}_{0.3125} \mathrm{O}_{3-\delta}$ is approximated as $\mathrm{Ba}_{0.5} \mathrm{Sr}_{0.5} \mathrm{~B}_{0.79^{-}}$ $\mathrm{Fe}_{0.21} \mathrm{O}_{3-\delta}$ (while keeping the total chemical stoichiometry of Bsite unchanged, $\mathrm{B}=\mathrm{Co}^{2+/ 3+}+\mathrm{W}^{6+}$ ). Thus, the relevant reactions in BSCFW for vacancy creation and the water uptake reaction are given as

$$
\mathrm{Fe}_{2} \mathrm{O}_{3}+2 \mathrm{~B}_{\mathrm{B}}^{\times}+\mathrm{O}_{\mathrm{O}}^{\times} \rightarrow 2 \mathrm{Fe}_{\mathrm{B}}{ }^{\prime}+\mathrm{V}_{\mathrm{O}}^{*}+2 \mathrm{BO}_{2}
$$

From TGA data, only $\left[\mathrm{OH}_{\mathrm{O}}^{-}\right]$could be obtained while both $\left[\mathrm{V}_{\mathrm{O}}^{*}\right]$ and $\left[\mathrm{O}_{\mathrm{O}}^{\times}\right]$are unknown. Under oxidising conditions, the acceptor $\left(\mathrm{Fe}^{3+}\right)$-doped perovskites can be oxidized in the process of consuming oxygen vacancies and generating electron holes.

$$
\frac{1}{2} \mathrm{O}_{2}+\mathrm{V}_{\mathrm{O}}^{*} \leftrightarrow \mathrm{O}_{\mathrm{O}}^{\times}+2 h \cdot
$$

Considering the overall electro-neutrality, then based on eqn (1), (3) and (4) above, eqn (5) could be obtained: 

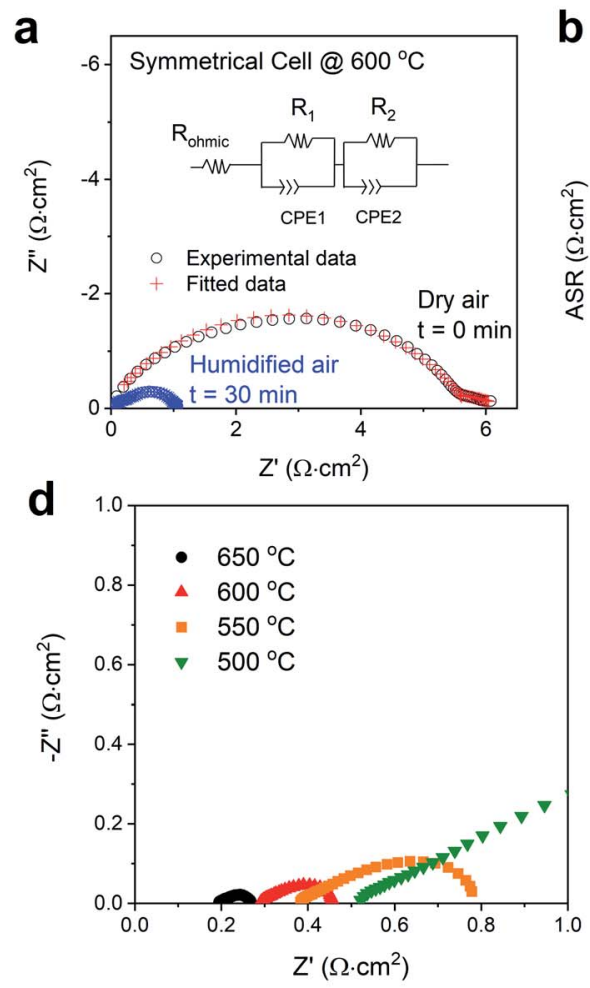
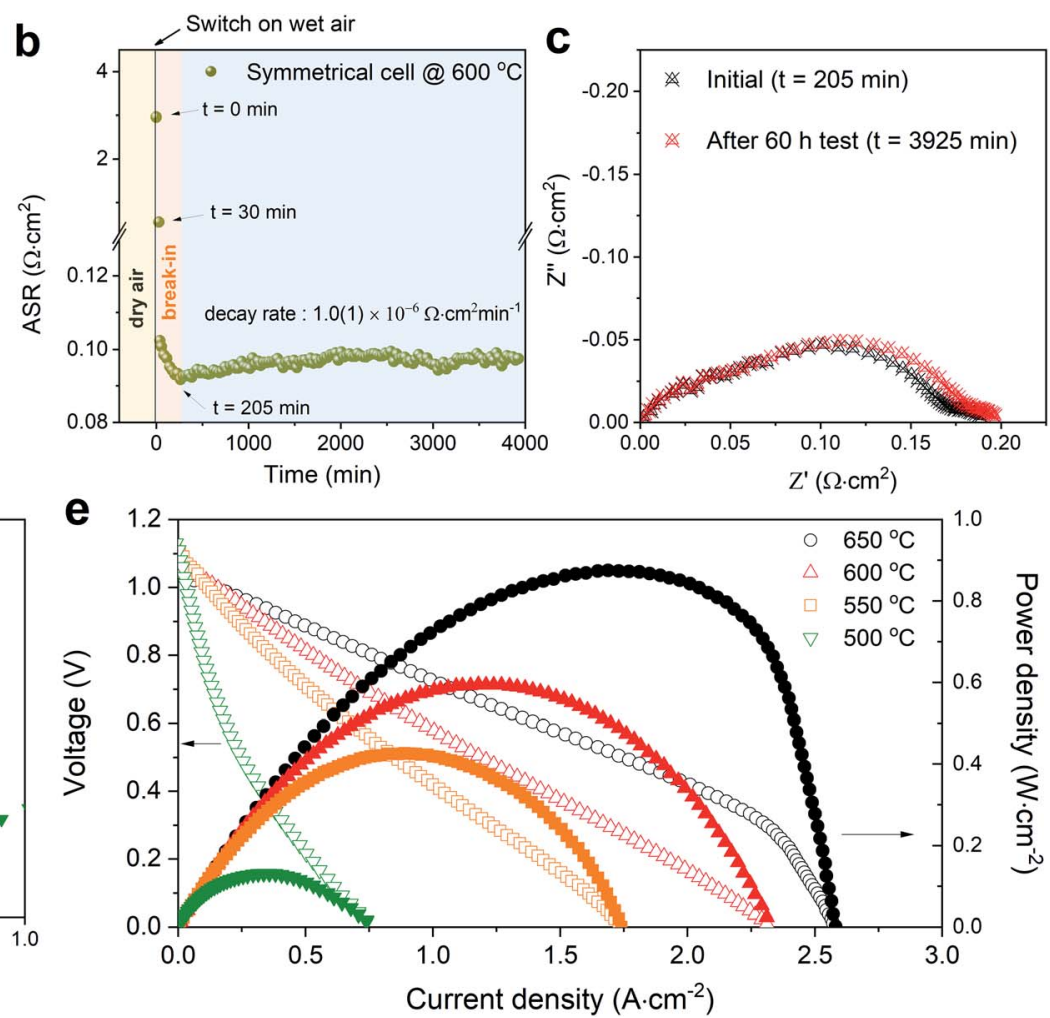

Fig. 3 (a) Impedance spectra (real vs. imaginary impedance) of a BSCFW|BZCYYb|BSCFW symmetrical cell under dry (black data points) and humidified 3 vol\% $\mathrm{H}_{2} \mathrm{O}$-containing air (blue datapoints) conditions at $600^{\circ} \mathrm{C}$. The ohmic resistance $\left(R_{\text {ohmic }}\right)$ including the contribution from the instrument and electrolyte is subtracted (the original impedance data is shown in Fig. S8 $\dagger$ ). The ASR of the cathode material is determined by the total resistance which is the sum of $R_{1}$ and $R_{2}$ (shown in the equivalent circuit diagram) (b) ASR of the symmetrical cell in 3 vol\% water-containing air showing a $205 \mathrm{~min}$ break-in period after which the ASR stabilised and increases with a decay rate of $1.0(1) \times 10^{-6} \Omega \mathrm{cm}^{2} \mathrm{~min}^{-1}$. (c) Impedance spectra plot of the symmetrical cell in Fig. $3 \mathrm{~b} t=205 \mathrm{~min}$ (after break-in period) and after the $60 \mathrm{~h}$ test ( $t=3925 \mathrm{~min}$ ). (d) Impedance spectra of the single cell (BSCFW|BZCYYb|NiO-BZCYYb) measured under open-circuit condition, A reduced scale is displayed to show detail at higher temperature (full-scale plot is shown in Fig. S9†). (e) I-V curve (open symbols) and corresponding power density curves (filled symbols) of the $\mathrm{BSCFW}$-BZCYYb single cell in the $500-650^{\circ} \mathrm{C}$ temperature range.

$$
2\left[\mathrm{~V}_{\mathrm{O}}^{*}\right]+\left[\mathrm{OH}_{\mathrm{O}}^{*}\right]+p=\left[\mathrm{Fe}_{\mathrm{B}}{ }^{\prime}\right]
$$

in which $\left[\mathrm{Fe}_{\mathrm{B}}{ }^{\prime}\right]$ is the concentration of $\mathrm{Fe}$ on B-site $\left(\left[\mathrm{Fe}_{\mathrm{B}}{ }^{\prime}\right]=0.21\right)$ and $p$ is the unknown hole concentration. Note there is also a constraint for the number of oxygen sites to sum to 3.

$$
\left[\mathrm{V}_{\mathrm{O}}^{*}\right]+\left[\mathrm{OH}_{\mathrm{O}}^{*}\right]+\left[\mathrm{O}_{\mathrm{O}}^{\times}\right]=3
$$

Using the above eqn (5) and (6), and as some studies reported, the hole concentration $p$ is negligible. ${ }^{34,35}$ Therefore the unknown $\left[\mathrm{V}_{\mathrm{O}}^{*}\right]$ and $\left[\mathrm{O}_{\mathrm{O}}^{\times}\right]$can be expressed as $\left[\mathrm{V}_{\mathrm{O}}^{*}\right]=\frac{1}{2}\left(\left[\mathrm{Fe}_{\mathrm{B}}{ }^{\prime}\right]-\left[\mathrm{OH}_{\mathrm{O}}^{*}\right]\right)$ and $\left[\mathrm{O}_{\mathrm{O}}^{\times}\right]=\frac{1}{2}\left(6-\left[\mathrm{OH}_{\mathrm{O}}^{*}\right]-\left[\mathrm{Fe}_{\mathrm{B}}{ }^{\prime}\right]\right)$, respectively.

Then the eqn (2) now could be expressed as

$$
K_{\mathrm{OH}}=\frac{4\left[\mathrm{OH}_{\mathrm{O}}^{\cdot}\right]^{2}}{P_{\mathrm{H}_{2} \mathrm{O}}\left(\left[\mathrm{Fe}_{\mathrm{B}}{ }^{\prime}\right]-\left[\mathrm{OH}_{\mathrm{O}}^{\prime}\right]\right)\left(6-\left[\mathrm{OH}_{\mathrm{O}}^{\cdot}\right]-\left[\mathrm{Fe}_{\mathrm{B}}{ }^{\prime}\right]\right)}
$$

Therefore, the equilibrium constant $\left(K_{\mathrm{OH}}\right)$ could be solved from known parameters. The proton uptake reaction is a thermally activated process, so the enthalpy of proton defect formation $(\Delta H)$ for BSCFW can be determined from the slope of the Arrhenius plot of equilibrium constants $\left(K_{\mathrm{OH}}\right)$ at different temperatures (Fig. 2a) using the following Van't Hoff equation, ${ }^{35}$

$$
\ln \left(K_{\mathrm{OH}}\right)=-\frac{\Delta H}{R T}+\frac{\Delta S}{R}
$$

where $R, T$, and $\Delta S$ are the universal gas constant, absolute temperature and entropy, respectively. For comparison, $\Delta H$ values of state-of-the-art PCOs are presented in Fig. 2b (specific TGA results are shown in Fig. S4 $\dagger$ ). The more negative values of $\Delta H$ (i.e., more exothermic) indicate that the hydration reaction is more favourable because of the relationship between the dissolved hydroxyl group and the lattice oxygen ${ }^{36,37}$ According to Sabatier's principle, the bond strength between the catalytic material and the reactant must be optimized for the ideal catalytic reaction. (i.e., not too strong or too weak bonding with reactants)..$^{38}$ In the temperature range of $400-800{ }^{\circ} \mathrm{C}$, the $\Delta H$ of proton defect formation for BSCFW is $-35 \pm 7 \mathrm{~kJ} \mathrm{~mol}^{-1}$, which is lower than the typical proton-conducting electrolyte materials BZY solid solutions $\left(-94 \mathrm{~kJ} \mathrm{~mol}^{-1}\right.$ to $\left.-66 \mathrm{~kJ} \mathrm{~mol}^{-1}\right),{ }^{39-43}$ but is comparable to the reported cathode materials for PCFC (BSFZ, $-70 \mathrm{~kJ} \mathrm{~mol}^{-1}$; 


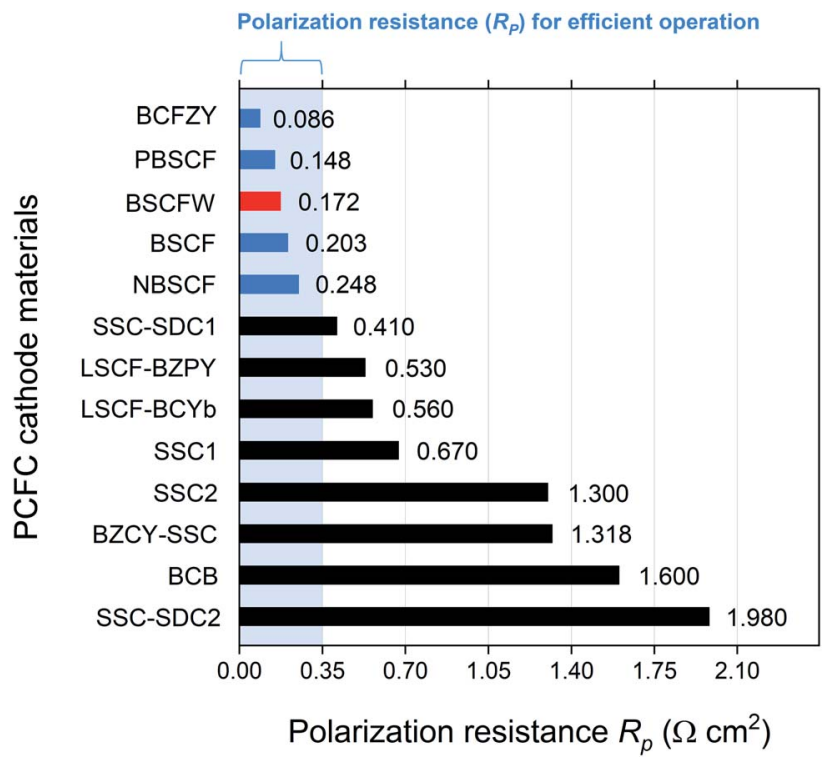

Fig. 4 Comparison of $R_{\mathrm{p}}$ of BSCFW (red) with other representative PCFC cathodes at $600{ }^{\circ} \mathrm{C}$. The values coloured in blue are the cathodes that have a value of lower than $0.35 \Omega \mathrm{cm}^{2}$ which allows efficient operation at a given temperature. $*\left(\mathrm{BaCO}_{0.4} \mathrm{Fe}_{0.4} \mathrm{Zr}_{0.1} \mathrm{Y}_{0.1} \mathrm{O}_{3-\delta}\right.$ (BCFZY), ${ }^{20} \quad \mathrm{PrBa}_{0.5} \mathrm{Sr}_{0.5} \mathrm{CO}_{1.5} \mathrm{Fe}_{0.5} \mathrm{O}_{5+\delta} \quad$ (PBSCF), ${ }^{52} \quad \mathrm{NdBa}_{0.5} \mathrm{Sr}_{0.5} \mathrm{CO}_{1.5^{-}}$ $\mathrm{Fe}_{0.5} \mathrm{O}_{5+\delta}$ (NBSCF), ${ }^{53} \mathrm{Sm}_{0.5} \mathrm{Sr}_{0.5} \mathrm{CoO}_{3-\delta}-\mathrm{Ce}_{0.8} \mathrm{Sm}_{0.2} \mathrm{O}_{2-\delta}$ on $\mathrm{BaZr}_{0.7^{-}}$ $\mathrm{Sr}_{0.1} \mathrm{Y}_{0.2} \mathrm{O}_{3-\delta}$ electrolyte (SSC-SDC1), ${ }^{54} \quad \mathrm{La}_{0.6} \mathrm{Sr}_{0.4} \mathrm{Fe}_{0.8} \mathrm{CO}_{0.2} \mathrm{O}_{3-\delta}-$ $\mathrm{BaZr}_{0.7} \mathrm{Pr}_{0.1} \mathrm{Y}_{0.2} \mathrm{O}_{3-\delta} \quad$ (LSCF-BZPY), ${ }^{55} \quad \mathrm{La}_{0.6} \mathrm{Sr}_{0.4} \mathrm{Fe}_{0.8} \mathrm{CO}_{0.2} \mathrm{O}_{3-\delta}-$ $\mathrm{BaCe}_{0.9} \mathrm{Yb}_{0.1} \mathrm{O}_{3-\delta} \quad$ (LSCF-BCYb), ${ }^{22} \mathrm{Sm}_{0.5} \mathrm{Sr}_{0.5} \mathrm{CoO}_{3-\delta}$ on $\mathrm{BaCe}_{0.8^{-}}$ $\mathrm{Sm}_{0.2} \mathrm{O}_{3-\delta}$ electrolyte (SSC1), ${ }^{56} \mathrm{Sm}_{0.5} \mathrm{Sr}_{0.5} \mathrm{CoO}_{3-\delta}$ on $\mathrm{BaZr}_{0.8} \mathrm{Y}_{0.2} \mathrm{O}_{3-\delta}$ electrolyte (SSC2), ${ }^{57} \mathrm{BaZr}_{0.1} \mathrm{Ce}_{0.7} \mathrm{Y}_{0.2} \mathrm{O}_{3-\delta}-\mathrm{Sm}_{0.5} \mathrm{Sr}_{0.5} \mathrm{CoO}_{3-\delta}$ (BZCY$\mathrm{SSC}),{ }^{58} \mathrm{BaCe}_{0.5} \mathrm{Bi}_{0.5} \mathrm{O}_{3-\delta}(\mathrm{BCB}),{ }^{59} \mathrm{Sm}_{0.5} \mathrm{Sr}_{0.5} \mathrm{CoO}_{3-\delta}-\mathrm{Ce}_{0.8} \mathrm{Sm}_{0.2} \mathrm{O}_{2-\delta}$ on $\mathrm{BaZr}_{0.1} \mathrm{Ce}_{0.7} \mathrm{Y}_{0.2} \mathrm{O}_{3-\delta}$ electrolyte (SSC-SDC2) ${ }^{60}$ ).

BL5FZn5, -47 $\mathrm{kJ} \mathrm{mol}^{-1}$ ), ${ }^{15,16}$ indicating that BSCFW has favourable proton uptake properties despite the considerable content of inactive DP phase (weight fraction: 70.7(4)\%). ${ }^{29}$

Fig. 3a shows impedance spectroscopy data measured from a BSCFW $|\mathrm{BZCYYb}| \mathrm{BSCFW}$ symmetrical cell at $t=0$ (which is when the atmosphere was switched from dry air to humidified 3\% vol$\mathrm{H}_{2} \mathrm{O}$ air) and at $t=30 \mathrm{~min}$, highlighting a rapid response in cathodic performance of BSCFW to humidified air. The area specific resistance (ASR) as measured in symmetrical cells decreases dramatically to $0.572(6) \Omega \mathrm{cm}^{2}$ at $t=30 \mathrm{~min}$ before reaching $0.092 \Omega \mathrm{cm}^{2}$ after a break-in equilibration period of 205 min, as observed in Fig. 3b which shows the evolution of ASR with time for a BSCFW|BZCYYb|BSCFW symmetrical cell under $3 \mathrm{vol} \% \mathrm{H}_{2} \mathrm{O}$-containing air at $600{ }^{\circ} \mathrm{C}$. After the break-in period, the ASR of the cell gradually increases from $0.092(1) \Omega \mathrm{cm}^{2}$ to $0.097(2)$ $\Omega \mathrm{cm}^{2}$ over $60 \mathrm{~h}$ (Fig. 3c compares the corresponding impedance spectra at $t=205$ and $3925 \mathrm{~min}$ ) yielding an ASR degradation rate of $1.0(1) \times 10^{-6} \Omega \mathrm{cm}^{2} \mathrm{~min}^{-1}$. For comparison, an equivalent experiment was attempted using BSCF but due to the large TEC mismatch between BSCF and BZCYYb, as described above, measurements were not possible because of delamination. Fig. S5 $\dagger$ shows the symmetrical cells of BSFCW and BSCF after preparation, clearly demonstrating delamination of the BSCF coating.

Next, a BSCFW $\mid$ BZCYYb $\mid$ NiO-BZCYYb single cell was assembled and tested. Fig. 3d and e present the electrochemical performance of a single cell with a configuration of $\mathrm{BSCFW}|\mathrm{BZCYYb}| \mathrm{NiO}-\mathrm{BZCYYb}$. Generally, the measured impedance spectra of a single cell are used to describe total resistances associated with components such as electrode and electrolyte. The intercept with the real axis at high frequencies represents the ohmic resistance which mainly originates from the electrolyte, whereas the difference between the high- and lowfrequency intercepts with the real axis indicates the sum of the electrode polarization resistance particularly from the cathode. As expected from the favourable protonic kinetic and thermodynamic properties presented by BSCFW, a small $R_{\mathrm{p}}$ of $0.172(2) \Omega \mathrm{cm}^{2}$ and a maximum power density of $0.582(1) \mathrm{W}$ $\mathrm{cm}^{-2}$ were obtained at $600{ }^{\circ} \mathrm{C}$ (Fig. $3 \mathrm{~d}$ and e) from the single cell measurement. Fig. S6a $\dagger$ shows the cross-section scanning electron microscopy image of the cell after the single cell test. There is no evidence of delamination or change of microstructure of the BSCFW cathode (Fig. S6b and $\mathrm{c} \dagger$ ).

The operational stability of the cell using BSCFW as cathode material was also examined at $600{ }^{\circ} \mathrm{C}$ for $8 \mathrm{~h}$ with a constant voltage of $0.6 \mathrm{~V}$ applied to the cell. For the cell stability test, $3 \mathrm{vol} \% \mathrm{H}_{2} \mathrm{O}$-containing $\mathrm{H}_{2}$ with a flow rate of $200 \mathrm{~mL} \mathrm{~min}^{-1}$ was supplied to the NiO-BZCY721 anode while air with a flow rate of

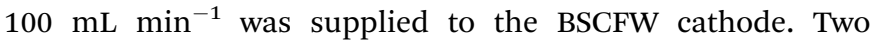
different electrolytes (BZCY721 and BZCYYb) were used to preliminarily examine their influence on the stability of cell. Note that the cell durability depends on not only the cathodeelectrolyte compositional combinations, but also anode, working gas, temperature and the applied voltage. ${ }^{45-47}$ More detailed evaluation with longer tests is required. As shown in Fig. S7, $\uparrow$ the power density of the cell using BZCY721 electrolyte decreased slightly (at the rate of $2.2(1) \times 10^{-5} \mathrm{~W} \mathrm{~cm}^{-2} \mathrm{~min}^{-1}$ ), which is lower that reported for LSCF-BZCY cell $\left(\mathrm{La}_{0.6} \mathrm{Sr}_{0.4^{-}}\right.$ $\mathrm{Co}_{0.2} \mathrm{Fe}_{0.8} \mathrm{O}_{3-\delta}$ cathode - BZCY electrolyte, approximately $3.3 \times$ $10^{-5} \mathrm{~W} \mathrm{~cm}^{-2} \mathrm{~min}^{-1}$, Table $\left.\mathrm{S} 2 \dagger\right)$. In addition, the power density decay rate of the cell using BSCFW cathode and BZCYYb electrolyte is $3.0(2) \times 10^{-4} \mathrm{~W} \mathrm{~cm}^{-2} \mathrm{~min}^{-1}$ (Fig. S7 $\dagger$ ), which is larger than that using BZCY721 electrolyte since the high Ce : Zr ratio $(7: 1)$ of BZCYYb increases the instability of the cell. ${ }^{10,48}$

Fig. 4 presents a comparison of $R_{\mathrm{p}}$ for BSCFW against representative PCFC cathodes materials. According to Steele et al., the total $R_{\mathrm{p}}$ of cell components (electrolyte, anode, and cathode) should be below $0.50 \Omega \mathrm{cm}^{2}$ to ensure high power densities, with targets of $1 \mathrm{~kW} \mathrm{dm}^{-3}$ and $1 \mathrm{~kW} \mathrm{~kg}^{-1} \cdot{ }^{49}$ Assuming that $30 \%$ of the total cell $R_{\mathrm{p}}$ is attributed to the electrolyte (i.e., a typical value of $\left.0.15 \Omega \mathrm{cm}^{2}\right),{ }^{50}$ an adequate performance is obtained from a PCFC if the electrode's $R_{\mathrm{p}}$ is less than 0.35 $\Omega \mathrm{cm}^{2}$. Notably, the $R_{\mathrm{p}}$ measured from the BSCFW single cell gives a value of $0.172(2) \Omega \mathrm{cm}^{2}$, which is less than half the recommended value and meets the requirement for efficient operation of a PCFC. Also, BSCFW shows a power density of $0.426(1) \mathrm{W} \mathrm{cm}{ }^{-2}$ even at $550{ }^{\circ} \mathrm{C}$, which is higher than the required power density of $0.25 \mathrm{~W} \mathrm{~cm}^{-2}$ for efficient operation ${ }^{51}$ (Table 1 and Fig. 4). Such efficient performance in the intermediate-to-low temperatures regime $\left(\sim 600{ }^{\circ} \mathrm{C}\right)$ enables cost-effective manufacturing by widening the choice of materials (e.g., metallic interconnects, non-ceramic seals) and eliminating major performance degradation. ${ }^{32}$ 
Table 1 Comparison of electrochemical performance for various PCFC single cells at $600{ }^{\circ} \mathrm{C}^{a}$

\begin{tabular}{|c|c|c|c|c|c|c|}
\hline Cathode & Electrolyte (thickness) & Anode & $\begin{array}{l}\text { Ohmic resistance } \\
\left(\Omega \mathrm{cm}^{2}\right)\end{array}$ & $R_{\mathrm{p}}\left(\Omega \mathrm{cm}^{2}\right)$ & $\begin{array}{l}\text { Maximum power } \\
\text { density }\left(\mathrm{W} \mathrm{cm}{ }^{-2}\right)\end{array}$ & Ref. \\
\hline BCFZY & BZCYYb $(20-30 \mu \mathrm{m})$ & Ni-BZCYYb & 0.295 & 0.086 & 0.65 & 20 \\
\hline BSCFW & BZCYYb $(15 \mu \mathrm{m})$ & Ni-BZCYYb & $0.272(3)$ & $0.172(2)$ & $0.582(1)$ & This work \\
\hline BSCF & BZCY $(25-40 \mu \mathrm{m})$ & Ni-BZCY & 1.226 & 0.203 & 0.544 & 23 \\
\hline NBSCF & 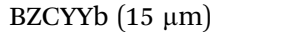 & Ni-BZCYYb & 0.128 & 0.248 & 0.7 & 53 \\
\hline LSCF-BCYb & $\mathrm{BZY}(20 \mu \mathrm{m})$ & Ni-BZY & 1.850 & 0.560 & 0.112 & 22 \\
\hline SSC & BCS $(70 \mu \mathrm{m})$ & Ni-BCS & 0.100 & 0.670 & 0.42 & 56 \\
\hline SSC & $\mathrm{BZY}(20 \mu \mathrm{m})$ & Ni-BZCY & 1.400 & 1.300 & 0.07 & 57 \\
\hline BZCY-SSC & $\mathrm{BZCY}(20 \mu \mathrm{m})$ & Ni-BZCY & 0.357 & 1.318 & 0.24 & 58 \\
\hline BCB & BZCY $(25 \mu \mathrm{m})$ & Ni-BZCY & 0.670 & 1.600 & 0.125 & 59 \\
\hline SSC-SDC & $\mathrm{BZY}(25 \mu \mathrm{m})$ & Ni-BZCY & 3.240 & 1.980 & 0.055 & 60 \\
\hline
\end{tabular}

${ }^{a}\left(\mathrm{BaCo}_{0.4} \mathrm{Fe}_{0.4} \mathrm{Zr}_{0.1} \mathrm{Y}_{0.1} \mathrm{O}_{3-\delta} \quad(\mathrm{BCFZY}), \quad \mathrm{BaZr}_{0.1} \mathrm{Ce}_{0.7} \mathrm{Y}_{0.1} \mathrm{Yb}_{0.1} \mathrm{O}_{3-\delta} \quad(\mathrm{BZCYYb}), \quad \mathrm{PrBa}_{0.5} \mathrm{Sr}_{0.5} \mathrm{Co}_{1.5} \mathrm{Fe}_{0.5} \mathrm{O}_{5+\delta} \quad(\mathrm{PBSCF}), \quad \mathrm{BaZr}_{0.4} \mathrm{Ce}_{0.4} \mathrm{Y}_{0.1} \mathrm{Yb}_{0.1} \mathrm{O}_{3-\delta}\right.$

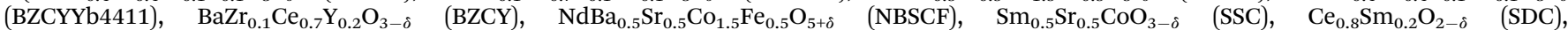
$\mathrm{BaZr}_{0.7} \mathrm{Sr}_{0.1} \mathrm{Y}_{0.2} \mathrm{O}_{3-\delta}$ (BZSY), $\mathrm{La}_{0.6} \mathrm{Sr}_{0.4} \mathrm{Fe}_{0.8} \mathrm{Co}_{0.2} \mathrm{O}_{3-\delta}$ (LSCF), $\mathrm{BaZr}_{0.7} \mathrm{Pr}_{0.1} \mathrm{Y}_{0.2} \mathrm{O}_{3-\delta} \quad$ (BZPY), $\mathrm{BaZr}_{0.8} \mathrm{Y}_{0.2} \mathrm{O}_{3-\delta} \quad(\mathrm{BZY}), \mathrm{BaCe}_{0.9} \mathrm{Yb}_{0.1} \mathrm{O}_{3-\delta} \quad(\mathrm{BCYb})$, $\left.\mathrm{BaCe}_{0.8} \mathrm{Sm}_{0.2} \mathrm{O}_{3-\delta}(\mathrm{BCS}), \mathrm{BaCe}_{0.5} \mathrm{Bi}_{0.5} \mathrm{O}_{3-\delta}(\mathrm{BCB})\right)$.

\section{Conclusions}

BSCFW, a self-assembled dynamic perovskite composite cathode, shows excellent chemical stability in contact with humidified air and the solid electrolyte (BZCYYb) at high temperatures, and electrochemical stability under PCFC operating conditions with a symmetrical cell showing a $R_{\mathrm{p}}$ degradation rate of $1.0(1) \times 10^{-6}$ $\Omega \mathrm{cm}^{2} \min ^{-1}$ over more than $60 \mathrm{~h}$ at $600{ }^{\circ} \mathrm{C}$. A single-cell test showed operational stability over $8 \mathrm{~h}$, with a power density decay rate of $2.2(1) \times 10^{-5} \mathrm{~W} \mathrm{~cm}^{-2} \mathrm{~min}^{-1}$. These initial stability tests give decay rates less than those found for LSCF electrodes in equivalent single cell configurations and require more detailed evaluation with longer tests. This performance is a significant improvement over BSCF, which was not stable under the same conditions and its TEC mismatch with BZCYYb prevented symmetrical cell testing. Thermodynamically, BSCFW has a favourable enthalpy value $(\Delta H)$ of proton defect formation $(-35$ $\pm 7 \mathrm{~kJ} \mathrm{~mol}^{-1}$ ) comparable to leading proton-conducting oxides. Such favourable protonic properties highlight the potential of BSCFW as a PCFC cathode material with high activity for operation at low temperatures (e.g. $550{ }^{\circ} \mathrm{C}$ ). Our identification of the self-assembled nanocomposite BSCFW as a high-performance PCFC cathode material, and comprehensive characterisation of thermodynamic behaviour provides fundamental scientific insight for the rational design of more efficient electrode materials for high-performance PCFCs.

\section{Data availability}

Underlying data is available at http://datacat.liverpool.ac.uk/id/ eprint/1409.

\section{Author contributions}

JK and DH designed and conducted the material synthesis, characterisation and electrochemical measurements and prepared the first draft of the manuscript. HN assisted with construction and operation of single-cell measurements. RF and BL assisted with TGA measurements. LD, TM, RC participated in the design of the experiment and provided assistance with data analysis and revision of the manuscript. All authors contributed to the discussion of the results and approved the final version of the manuscript. MJR directed the research.

\section{Conflicts of interest}

There are no conflicts to declare.

\section{Acknowledgements}

This work was funded by the EPSRC Programme Grant EP/ N004884/1. DH and BL thank the China Scholarship Council (CSC) for studentship funding (201706280042 and 2018064500).

\section{References}

1 S. Sengodan, S. Choi, A. Jun, T. H. Shin, Y.-W. Ju, H. Y. Jeong, J. Shin, J. T. Irvine and G. Kim, Nat. Mater., 2015, 14, 205209.

2 Y. Zhang, B. Chen, D. Guan, M. Xu, R. Ran, M. Ni, W. Zhou, R. O'Hayre and Z. Shao, Nature, 2021, 591, 246-251.

3 J. S. Ahn, S. Omar, H. Yoon, J. C. Nino and E. D. Wachsman, J. Power Sources, 2010, 195, 2131-2135.

4 F. Baumann, J. Maier and J. Fleig, Solid State Ionics, 2008, 179, 1198-1204.

5 E. Bucher, A. Egger, G. Caraman and W. Sitte, J. Electrochem. Soc., 2008, 155, B1218.

6 K. Kreuer, Chem. Mater., 1996, 8, 610-641.

7 H. Iwahara, T. Esaka, H. Uchida and N. Maeda, Solid State Ionics, 1981, 3, 359-363.

8 H. Iwahara, Solid State Ionics, 1996, 86, 9-15.

9 C. Zhang and H. Zhao, Solid State Ionics, 2012, 206, 17-21. 
10 P. Sawant, S. Varma, B. Wani and S. Bharadwaj, Int. J. Hydrogen Energy, 2012, 37, 3848-3856.

11 K. Xie, R. Yan, X. Chen, D. Dong, S. Wang, X. Liu and G. Meng, J. Alloys Compd., 2009, 472, 551-555.

12 L. Yang, S. Wang, K. Blinn, M. Liu, Z. Liu, Z. Cheng and M. Liu, Science, 2009, 326, 126-129.

13 A. VahidMohammadi and Z. Cheng, J. Electrochem. Soc., 2015, 162, F803-F811.

14 R. Zohourian, R. Merkle and J. Maier, Solid State Ionics, 2017, 299, 64-69.

15 R. Zohourian, R. Merkle, G. Raimondi and J. Maier, Adv. Funct. Mater., 2018, 28, 1801241.

16 D. Poetzsch, R. Merkle and J. Maier, Faraday Discuss., 2015, 182, 129-143.

17 H. Kawamori, I. Oikawa and H. Takamura, Chem. Mater., 2021, 33, 5935-5942.

18 Y. Meng, J. Gao, Z. Zhao, J. Amoroso, J. Tong and K. S. Brinkman, J. Mater. Sci., 2019, 54, 9291-9312.

19 N. L. R. M. Rashid, A. A. Samat, A. A. Jais, M. R. Somalu, A. Muchtar, N. A. Baharuddin and W. N. R. W. Isahak, Ceram. Int., 2019, 45, 6605-6615.

20 C. Duan, J. Tong, M. Shang, S. Nikodemski, M. Sanders, S. Ricote, A. Almansoori and R. O'Hayre, Science, 2015, 349, 1321-1326.

21 D. Poetzsch, R. Merkle and J. Maier, Phys. Chem. Chem. Phys, 2014, 16, 16446-16453.

22 J. Kim, S. Sengodan, S. Kim, O. Kwon, Y. Bu and G. Kim, Renewable Sustainable Energy Rev., 2019, 109, 606-618.

23 E. Fabbri, D. Pergolesi and E. Traversa, Chem. Soc. Rev., 2010, 39, 4355-4369.

24 T. Norby, Solid State Ionics, 1999, 125, 1-11.

25 Z. Shao and S. Haile, Nature, 2004, 431, 170-173.

26 N. Bausá, C. Solís, R. Strandbakke and J. M. Serra, Solid State Ionics, 2017, 306, 62-68.

27 A. Grimaud, F. Mauvy, J. Bassat, S. Fourcade, L. Rocheron, M. Marrony and J. Grenier, J. Electrochem. Soc., 2012, 159, B683.

28 S. Sun and Z. Cheng, J. Electrochem. Soc., 2016, 164, F81.

29 J. F. Shin, W. Xu, M. Zanella, K. Dawson, S. N. Savvin, J. B. Claridge and M. J. Rosseinsky, Nat. Energy, 2017, 2, 16214.

30 X. Zhou, L. Liu, J. Zhen, S. Zhu, B. Li, K. Sun and P. Wang, J. Power Sources, 2011, 196, 5000-5006.

31 W. Zhou, R. Ran, Z. Shao, W. Jin and N. Xu, J. Power Sources, 2008, 182, 24-31.

32 E. D. Wachsman and K. T. Lee, Science, 2011, 334, 935-939.

33 Z. Gao, L. V. Mogni, E. C. Miller, J. G. Railsback and S. A. Barnett, Energy Environ. Sci., 2016, 9, 1602-1644.

34 Y. Yamazaki, P. Babilo and S. M. Haile, Chem. Mater., 2008, 20, 6352-6357.
35 K. Kreuer, W. Münch, A. Fuchs, U. Klock and J. Maier, Solid State Ionics, 2001, 145, 295-306.

36 R. Haugsrud and T. Norby, Nat. Mater., 2006, 5, 193-196.

37 T. Norby, M. Widerøe, R. Glöckner and Y. Larring, Dalton Trans., 2004, 3012-3018.

38 Z. W. Seh, J. Kibsgaard, C. F. Dickens, I. Chorkendorff, J. K. Nørskov and T. F. Jaramillo, Science, 2017, 355.

39 C. Kjølseth, L.-Y. Wang, R. Haugsrud and T. Norby, Solid State Ionics, 2010, 181, 1740-1745.

40 S. Eisele, F. M. Draber and S. Grieshammer, Phys. Chem. Chem. Phys., 2021, 23, 4882-4891.

41 H. Zhu, S. Ricote, C. Duan, R. P. O'Hayre, D. S. Tsvetkov and R. J. Kee, J. Electrochem. Soc., 2018, 165, F581.

42 K.-D. Kreuer, Annu. Rev. Mater. Res., 2003, 33, 333-359.

43 S. Ricote, N. Bonanos and G. Caboche, Solid State Ionics, 2009, 180, 990-997.

44 K. Kreuer, T. Dippel, Y. M. Baikov and J. Maier, Solid State Ionics, 1996, 86, 613-620.

45 K. Zhu, Y. Yang, D. Huan, X. Hu, N. Shi, Y. Xie, X. Li, C. Xia, R. Peng and Y. Lu, ChemSusChem, 2021, 14, 3876-3886.

46 D. Huan, L. Zhang, X. Li, Y. Xie, N. Shi, S. Xue, C. Xia, R. Peng and Y. Lu, ChemSusChem, 2020, 13, 4994-5003.

47 M. Hakim, C.-Y. Yoo, J. H. Joo and J. H. Yu, J. Power Sources, 2015, 278, 320-324.

48 E. Fabbri, A. D'Epifanio, E. Di Bartolomeo, S. Licoccia and E. Traversa, Solid State Ionics, 2008, 179, 558-564.

49 B. Steel and A. Heinzel, Nature, 2001, 414, 345-352.

50 D. J. Brett, A. Atkinson, N. P. Brandon and S. J. Skinner, Chem. Soc. Rev., 2008, 37, 1568-1578.

51 A. Weber and E. Ivers-Tiffée, J. Power Sources, 2004, 127, 273283.

52 S. Choi, C. Kucharczyk, Y. Liang, X. Zhang, I. Takeuchi, H. Ji and S. Haile, Nat. Energy, 2018, 3, 202-210.

53 J. Kim, S. Sengodan, G. Kwon, D. Ding, J. Shin, M. Liu and G. Kim, ChemSusChem, 2014, 7, 2811-2815.

54 W. Sun, M. Liu and W. Liu, Adv. Energy Mater., 2013, 3, 10411050.

55 E. Fabbri, L. Bi, J. L. Rupp, D. Pergolesi and E. Traversa, RSC Adv., 2011, 1, 1183-1186.

56 T. Wu, R. Peng and C. Xia, Solid State Ionics, 2008, 179, 15051508.

57 W. Sun, L. Yan, Z. Shi, Z. Zhu and W. Liu, J. Power Sources, 2010, 195, 4727-4730.

58 S. Lee, I. Park, H. Lee and D. Shin, Int. J. Hydrogen Energy, 2014, 39, 14342-14348.

59 Z. Tao, L. Bi, L. Yan, W. Sun, Z. Zhu, R. Peng and W. Liu, Electrochem. Commun., 2009, 11, 688-690.

60 J. Xiao, W. Sun, Z. Zhu, Z. Tao and W. Liu, Mater. Lett., 2012, 73, 198-201. 